\title{
Comic as Literacy Media
}

\author{
Wasana $^{1}$, H N Hidayat ${ }^{2}$, E Meigalia $^{3}$, R Almos $^{4}$ \\ 1,2,3, ${ }^{4}$ Universitas Andalas \\ \{wasana@hum.unand.ac.id ${ }^{1}$, herrynh@hum.unand.ac.id², ekameigalia@fib.unand.ac.id ${ }^{3}$, \\ ronaalmos@hum.unand.ac.id $\left.{ }^{4}\right\}$
}

\begin{abstract}
This article describes traditional literary works created for literacy media. As a variety of traditional prose, kaba has a distinctiveness compared to other traditional Minangkabau literary works. Besides it's unique, kaba fully loaded with Minangkabau contents. The transformation was expected to be used as literacy media and bring traditional literature closer to the younger generation. Besides literacy activities have not been maximized, the provision of suitable reading materials is still a problem that affects the level of understanding and criticality of the reader. The contents of books dominated by text are still an option in the provision of reading material. Pictures as reading material have not become an alternative to meeting reading material needs
\end{abstract}

Keywords: Kaba, Comic, Minangkabau, Literacy

\section{INTRODUCTION}

Basically, the literacy level of a community shows it's intelligence level. Literacy also related to the level of knowledge and understanding. It means that literacy is not only related to reading and writing activity. Therefore, to improve literacy skills, it is needed the right media. As a tool for supporting the process, it is important to decide the quality of the material so that the information obtained will be more meaningful. In addition, the ease of obtaining reading sources will affects the frequency of someone reading. The more a person does reading activities, the more information he gets. Indirectly there will be more ideas realized in written form[1].

In addition, as far as the author's observation, GLS is still limited to reading activity. The 15-minute activity of reading non-learning books in schools has not been continued with critical activities to spur writing activities. Hundreds of titles of literacy reading material published by Badan Pengembangan Bahasa dan Perbukuan since 2016 to 2018 [2]-[4] has not been used optimally. Even though the contents that are in it are diverse, it has the potential to invite the critical mindset of the reader.

Besides literacy activities have not been maximized, the provision of suitable reading materials is still a problem that affects the level of understanding and criticality of the reader. The contents of books dominated by text are still an option in the provision of reading material. Pictures as reading material have not become an alternative to meeting reading material needs. According to Gillenwater [5], developing literacy must consider the ability of readers to interpret and create patterns of reaching meaning, one way is through graphic novels or comics. The combination of images and text will help the reader interpretations reach meaning. 
The study of graphic novels and comics in an effort to develop a literacy culture is not new. Through the study of X-Men comics, Gerde [6] states that the use of comics for learning facilities can undermine cultural boundaries and increase understanding in decision making both personal and group.Smetana [7], images can communicate ideas and emotions. Related on literacy, images can trigger readers to use their knowledge to fill the void of dialogue in comics and in some parts can foster the sensitivity of readers' feelings. Seglem [8] also argues that images are a very good instruction tool and because readers receive information in a variety of formats, literacy must also go beyond traditional reading and writing methods by maximizing the images as a way of communicating.

Efforts to design comics as literacy media have been carried out. Bitz[9]in his project concluded communication and expression are key in literacy. Forming expressive communication, creativity, and personal abilities can emerge through comic reading. Dhien [10] designed the Hyang comic as a medium for introducing wayang to the younger generation. McVicker [11] made and used comic strips in the development of visual literacy. His study concluded through a visual form, readers can help develop their literacy skills. Sasmita [12] conducted a comic design to socialize the 4 pillars of Indonesian nationality. Ramliyana [13] designed comics in an effort to foster learning motivation for BIPA learners (Indonesian for Foreign Speakers). Zhu [14]carried out the project of creating comics for information literacy in the context of socializing transportation in Shanghai, China.

As one of traditional Minangkabau literary works, kaba has distinctiveness and uniqueness. The form is a combination of poetry and prose genres. Junus[15]states kaba narrated through poetry and narrating a story. Even though it is a pantun, the story unit in kaba is not in line and verse. Therefore, $k a b a$ is referred to as lyrical prose[16], [17]. Typically, $k a b a$ does not tell the origin of the formation of adat, but rather relates to the ways of everyday social life. $\mathrm{Kaba}$ is sometimes a mixture of ideal universal concepts with local traditions. Kaba is a mere literary work or legend about a local hero[18]. Junus[15]also mentions that every kaba is always related and contains elements and aspects of Minangkabau life and culture. Kaba also derived another tradition, randai, a combination of narrative and dramatic expression. Another unique feature of $k a b a$ is that, because it was delivered verbally by tukangkaba, kaba will always live and developed into new variants.

Because of the contents, it suitable if $k a b a$ is used as literacy media. The Minangkabau contents, both customs, culture, the social life of the community, and others could be applied as multimodal literacy media. As mentioned above, literacy is not only reading and writing but also activities of understanding knowledge and information. Wiedarti[19]states that the literacy component consists of early literacy, basic literacy, library literacy, media literacy, technology literacy, and visual literacy.

A reader is required to be able to "read" the message so it also requires the ability to analyze, and interpret. This literacy ability will be achieved easily in the visual form. The visual format gives the reader the ability to uncover and reconstruct the codes of an image rather than being a passive recipient[20]. In the end, various forms of literacy media are needed to improve the reconstruction capacity and readers' understanding of reading material[21].

Reading comics can foster children's imagination. Comics can be used as a model that can develop a child's personality. William[22]states that comics is a good tool to grow the critical skills of readers in interpreting a knowledge concept. McLaughlin [23] argues that comics, within the scope of their language and understanding, are filled with philosophical struggles. In the process of reading, comic readers face theoretical knowledge through stories, narratives, and images. 
In his study of comics development for two decades, [24]concluded that comic readers through narratives, stories, characters, even drawing panels, can focus more on expanding knowledge based on their experience. The meaning achievement in the literacy process requires interpretation. Quoting Wolfgang Iser who statedthe meaning in the text was collected by the reader through construction, deconstruction, and reconstruction of meaning in the process of reading in the form of imaging, [5] argued that imaging in the reading process could be developed through visual or image text.

Students will receive and understand easily the material and content in the comic. There are many comics that contain positive values. It is common that students will prefer to read comics rather than textbooks. In fact, some introductory textbooks have been transformed into comic forms [25]. Comics as educational media have giving readers a quick understanding of something. The use of images in textbooks is considered information that is easy to understand even though it is displayed with simple images. Comics are able to provide value in education towards mental, logical and spiritual intelligence[26].

From the discussion above, pictorial stories are one literacy media for multimodal literacy. Through images, readers can achieve meaning more easily. Based on knowledge and experience, the perceptions captured by the reader through images can also trigger wider-butdirected imagination, not free imagination.

\subsection{Research Method}

This transformation process uses a qualitative method. This method emphasizes the interpretation of the object for the next transformation step, the production. Selected kaba in this transformation is kabaSabai Nan Aluih. This selection based on research results[27]which concludes that kaba are rich with learning content in them, one of them is Sabai Nan Aluih. The interpretation step in this transformation also involves observation of Minangkabau content that can emerge as part of the story.Meanwhile, the steps in this process consist of preproduction, production, and postproduction. The preproduction step is object interpretation, the production step is the drawing, and the postproduction step is publication.This paper presents part of the preproduction process, which is the interpretation and modification of the story for kaba transformation into comics.

\subsection{Result and Discussion}

The first step in preproduction is deciding the image style. The team decides the style adopt the Japanese comic or manga based on the fact that manga has dominated the comic market in Indonesia. In addition, the familiarity readers with manga can be an attraction for the transformation results because of the well-known style. 


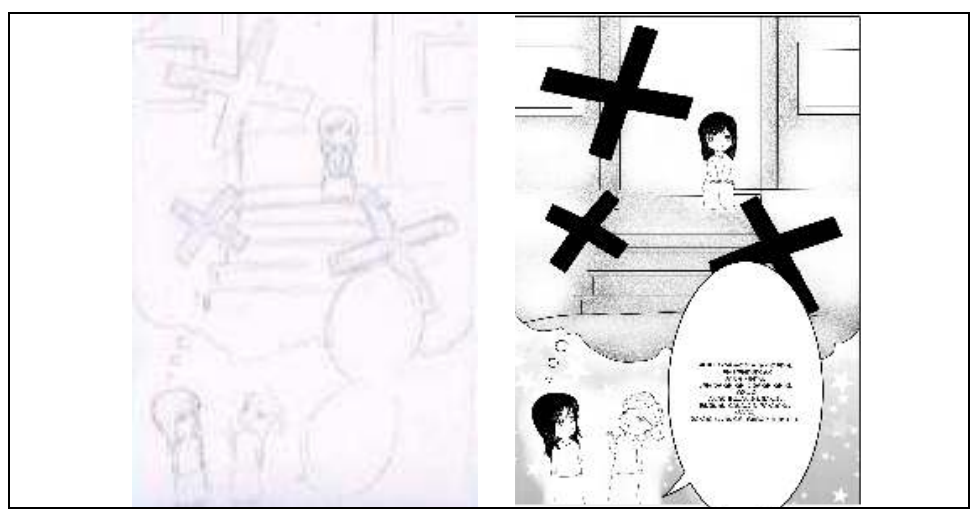

Figure 1. The Manga Style of Sabai Nan Aluih.

The next step is the visual interpretation of the characters, settings, and plot. The interpretation of characterizations is important in forming the character as the message carrier in the story. Sabai figure in kaba occurs as a girl with almost perfect both physically and personality.

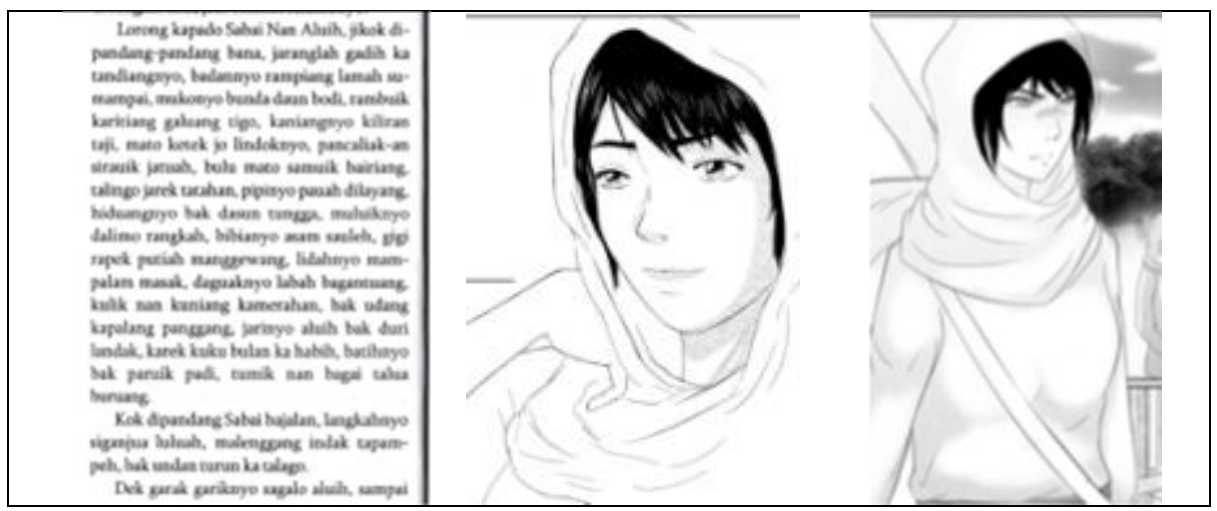

Figure 2. Visual interpretation of Sabai.

The depiction of Sabai (Figure 2) is based on the kaba and the imagery of women in Minangkabau proverbs,limpapehrumah nan gadang, umbun puro pagangankunci, pusekjalokumpulantali, sumarakdalamkampuang, hiasandalamnagari. Ronsi[28] explained that besides their beauty and behavior as a center in homes, villages, and nagari, girls in Minangkabau were educated to behave politely and skillfully manage the household. Minangkabau girls also have the image of being patient, merciful, assertive, firm, diligent, wise, and alert [28]-[30]. The interpretation of Sabai is expressed in the picture that shows Sabai as a beautiful and attractive but firm girl.

Interpretation of events in the kaba also considers the content of information about Minangkabau. Background, tradition, culture, even traditional games are maximally performed in this comic. 


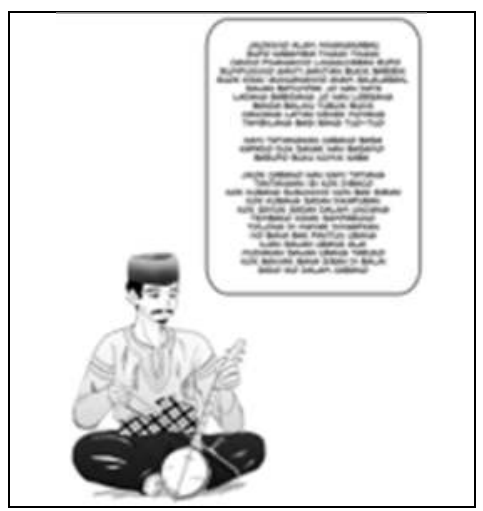

Figure 3. Tukangkaba.

Because of the source, tukangkaba(Figure 3) as performer must be presented in this comic. $\mathrm{Kaba}$ is usually delivered by man orally by singing which is usually accompanied by a musical instrument like saluang or rabab[16], [30].
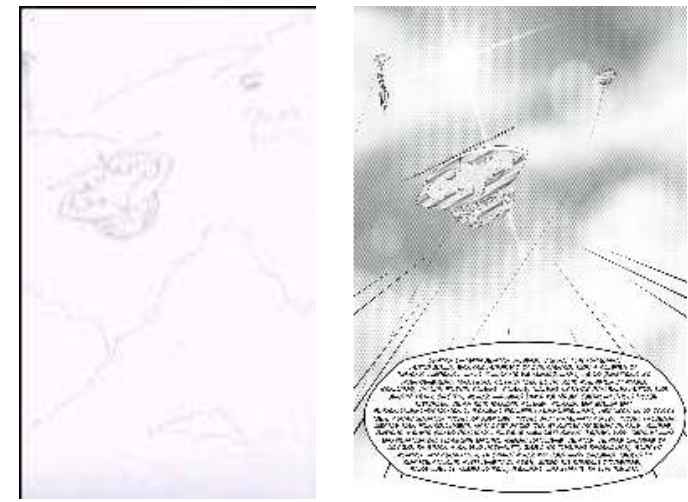

Figure 4. Playing kites.

For Minangkabaunesse, the traditional kite has a deep philosophy. However, known merely as a game it's philosophical education is now unexplored. We can learn about patience, perseverance, full consideration, and tolerance in the making and playing kites (Figure 4). 

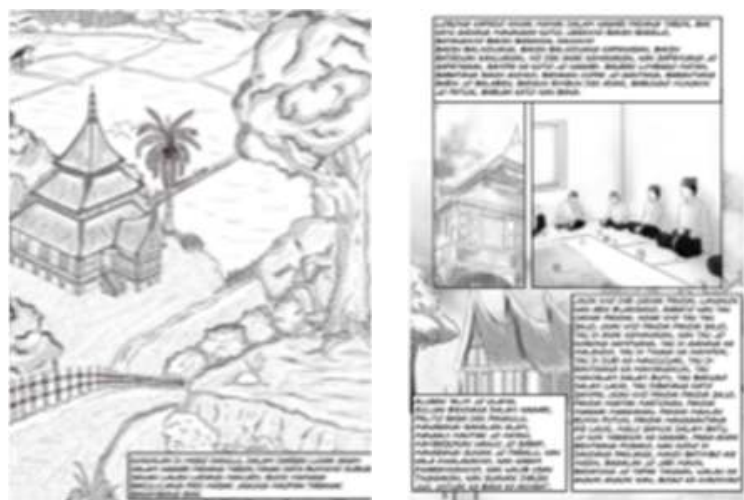

Figure 5. Surau and social activities at rumahgadang.

At present, surau is known as an Islamic worship place. However, not many know it's history, characteristics, and functions in the term of Minangkabau tradition. Surau is a cultural building of the Minangkabaunesse before the arrival of Islam. Usually, surau is built on the highest place or at least higher than other buildings (Figure 5) and also believed existed before Islam arrive in Minangkabau and was used as worship to Hinduism and Buddhism[31], [32]. Islam arrival into Minangkabau turned surau role and function into the education place of Islam[31]-[36]. Through the visualization, readers can obtain information that surau is different from the mosque and has characteristics that show the social life of the Minangkabau people.

Meanwhile, the visualization of rumahgadang(Figure 5) will inform that the role and function is not just a house. According to Franzia[37], through architecture, construction, decoration inside and outside, and the function, rumahgadang reflect cultural and spiritual values. Rumahgadang is a symbol of the communal life of the Minangkabau society in addition to its function as a democratic communication marks in Minangkabau[38], [39].
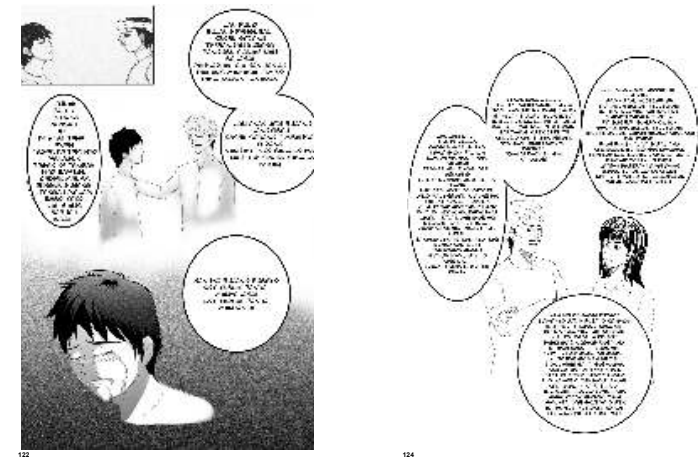

Figure 6. Advice of behaves.

Minangkabau custom is designed based on common sense, a combination of thoughts to consider good and bad refers to alamtakambangjadi guru, raso jo pareso (feeling/intention with check/control) which adjusting to alua jo patuik (groove and proper).It will decide to action (good attitude and behavior) by considering courtesy, in order to bring up the wisdom 
and behave in a civilized society. Minangkabau custom provides a guideline that arises from intention in living, thus providing actions and behaviors that reflect the typical character of the Minangkabaunesse[40], [41] [42]. This modification of Sabai Nan Aluih comic inserts elements of traditional wisdom of Minangkabau society. As an example, understanding of bujang nan ampek and gadih nan ampek as a guide for Minangkabau young men and women is included in one of the episodes in this comic.

\section{CONCLUSIONS}

Literacy is not merely reading and writing. Literacy is the process of receiving, gaining meaning and digesting information. With the right media, literary expertise can develop with habituation. Comics, as a transformation of traditional works, can be used as a multimodal literacy media that includes several components. Besides the visual form that attracts reading habituation, the content in $k a b a$ is the right device for literacy. The peculiarity of the kaba is a combination of poetry and prose, the content of both the language, custom, and tradition is the element which is rightly used as a means of information and cultural literacy.

\section{REFERENCES}

[1] S. Pujiono, "Berpikir Kritis dalam Literasi Membaca dan Menulis untuk Memperkuat Jati Diri Bangsa," Pengemb. Kebahasaan dan Kesusastraan melalui Nilai-Nilai Kearifan Lokal untuk Penguatan Jati Diri Bangsa, pp. 778-783, 2012.

[2] Badan Pengembangan Bahasa dan Perbukuan, "Buku Bahan Bacaan Literasu 2016 Badan Pengembangan dan Pembinaan Bahasa | Kementerian Pendidikan dan Kebudayaan," $2016 . \quad$ [Online]. Available: http://badanbahasa.kemdikbud.go.id/lamanbahasa/statik/2234.

[3] Badan Pengembangan Bahasa dan Perbukuan, "Bahan Bacaan Literasi 2017 | Badan Pengembangan dan Pembinaan Bahasa," 2017. [Online]. Available: http://badanbahasa.kemdikbud.go.id/lamanbahasa/content/bahan-bacaan-literasi-2017.

[4] Badan Pengembangan Bahasa dan Perbukuan, "Bahan Bacaan Literasi 2018 | Badan Pengembangan dan Pembinaan Bahasa," 2018. [Online]. Available: http://badanbahasa.kemdikbud.go.id/lamanbahasa/content/bahan-bacaan-literasi-2018.

[5] C. Gillenwater, "Lost literacy: How graphic novels can recover visual literacy in the literacy classroom," Afterimage, vol. 37, no. 2, pp. 33-36, 2009.

[6] V. W. Gerde and R. S. Foster, "X-Men Ethics: Using Comic Books to Teach Business Ethics," J. Bus. Ethics, vol. 77, pp. 245-258, 2008.

[7] L. Smetana, D. Odelson, H. Burns, and D. L. Grisham, "Using Graphic Novels in the High School Classroom: Engaging Deaf Students With a New Genre," J. Adolesc. Adult Lit., vol. 53, no. 3, pp. 228-240, 2009.

[8] R. Seglem and S. Witte, "You Gotta See It to Believe It : Teaching Visual Literacy in the English Classroom," J. Adolesc. Adult Lit., vol. 53, no. 3, pp. 216-226, 2009.

[9] M. Bitz, "The Comic Book project: Forging alternative pathways to literacy," J. Adolesc. Adult Lit., vol. 47, no. 7, pp. 574-588, 2004.

[10] K. Dhien, "Perancangan Komik Hyang dalam Menumbuhkan Apresiasi Generasi Muda kepada Kesenian Wayang," Surakarta, 2006.

[11] C. J. McVicker, "Comic Strips as a Text Structure for Learning to Read," Read. Teach., vol. 61 , no. 1 , pp. 85-88, 2007. 
[12] O. Sasmita, I. Ardana, and T. Handoko, "Perancangan Komik Sosialisasi 4 Pilar Kehidupan Berbangsa untuk Remaja," J. DKV Univ. Kristen Petra, vol. 1, no. 2, 2013.

[13] R. Ramliyana, "Membangkitkan Motivasi Belajar Bahasa Indonesia bagi Penutur Asing (BIPA) melalui Media Komik," Dialekt. J. Bahasa, Sastra, dan Pendidik. Bhs. dan Sastra Indones., vol. 3, no. 1, pp. 1-19, Dec. 2016.

[14] H. Zhu, A Science Comic of Urban Metro Structure. Shanghai: Tongji University Press Springer, 2019.

[15] U. Junus, "Kaba: An Unfinished (His-) Story,” Southeast Asian Stud., vol. 32, no. 3, pp. 399-415, 1994.

[16] E. Djamaris, Pengantar Sastra Rakyat Minangkabau. Jakarta: Yayasan Obor, 2002.

[17] A. A. Navis, Alam Terkembang Jadi Guru. Jakarta: Grafitti Press, 1984.

[18] T. Abdullah, "Beberapa Catatan Tentang Kaba Cinuda Mato: Satu Contoh Sastera Tradisional Minangkabau," J. Terjem. Alam Tamadun Melayu, vol. 1, pp. 117-137, 2009.

[19] P. Wiedarti et al., Desain Induk Gerakan Literasi Sekolah. Jakarta: Direktorat Jenderal Pendidikan Dasar dan Menengah Kementerian Pendidikan dan Kebudayaan, 2016.

[20] A. Fatimah and K. Maryani, "Visual literasi media pembelajaran buku cerita anak," $J$. Inov. Teknol. Pendidik., vol. 5, no. 1, p. 61, Oct. 2018.

[21] A. Schwartz and E. Rubinstein-ávila, "Understanding the manga hype: Uncovering the multimodality of comic-book literacies," J. Adolesc. Adult Lit., vol. 50, no. 1, pp. 40-49, 2006.

[22] R. M.-C. Williams, "Image, Text, and Story: Comics and Graphic Novels in the Classroom," Art Educ., vol. 61, no. 6, p. 13, 2008.

[23] J. McLaughlin, Ed., Comics as Philosophy. Mississippi: University Press ofMississippi / Jackson, 2005.

[24] A. Ndalianis, "Why Comics Studies ?," Cine. J., vol. 50, no. 3, 2011.

[25] H. N. Hidayat, Wasana, and E. Meigalia, "Komik Kaba: Bahan Pengayaan Pembelajaran Muatan Lokal Minangkabau," in Seminar dan Rapat Tahunan BKS PTN Wialayah Barat Bidang Bahasa, Sastra, Seni, dan Budaya, 2015, p. 165.

[26] N. Soedarso, "Komik: Karya Sastra Bergambar," Humaniora, vol. 6, no. 4, pp. 496-506, 2015.

[27] H. N. Hidayat, Wasana, and Kadrianto, "ALIH MEDIA KABA : Alternatif Revitalisasi Sastra Minangkabau,” Ling. Idea, vol. 4, no. 2, 2013.

[28] G. Ronsi, "CITRA PEREMPUAN DALAM PERIBAHASA MINANGKABAU," WACANA Etn., vol. 2, no. 1, pp. 39-58, Apr. 2011.

[29] N. Syahrul, "CITRA PEREMPUAN DALAM KABA ANGGUN NAN TUNGGA KARYA AMBAS MAHKOTA,” JENTERA J. Kaji. Sastra, vol. 2, no. 2, Jun. 2017.

[30] N. Andriani, H. WS, and M. I. Nst., "Citra Perempuan Minangkabau dalam Kaba Bujang Piaman jo Puti Payuang Lauik Versi Selasih," MARKAH J. Pendidik. Bhs. dan Sastra Indones., vol. 1, no. 1, pp. 681-686, 2012.

[31] Mhd. Natsir, "Peranan Surau Sebagai Lembaga Pendidikan Islam Tradisional Di Padang Pariaman Sumatera Barat (Surau Syaikh Burhanuddin)," Pedagog. J. Ilmu Pendidik., vol. 12, no. 2, pp. 39-46, Nov. 2006.

[32] S. Anam, "Karakteristik dan Sistem Pendidikan Islam: Mengenal Sejarah Pesantren, Surau dan Meunasah di Indonesia," JALIE; J. Appl. Linguist. Islam. Educ., vol. 1, no. 1, pp. 146-167, Mar. 2017.

[33] M. I. M. Taib, "Robohnya surau Kami: Menilai Kembali Peran Agama di Dalam Masyarakat," pp. 1-14, 2007. 
[34] D. Z. Kling, "Islam dan Kebudayaan Alam Melayu." Universiti Malaya, Kuala Lumpur, pp. 1-39, 2007.

[35] S. Hanani, "Difusi Ajaran dan Pemikiran Ulama dalam Sejarah Islam Minangkabau."

[36] M. Mawangir, "Modernization Of Islamic \&quot;Surau\&quot;; Traditional Education In West Sumatera, Indonesia," J. Islam. Stud., vol. 3, no. 2, pp. 2333-5912, 2015.

[37] E. Franzia, Y. A. Piliang, and A. I. Saidi, "Rumah Gadang as a Symbolic Representation of Minangkabau Ethnic Identity," Int. J. Soc. Sci. Humanit., vol. 5, no. $1,2015$.

[38] Noviarti, R. Irsa, and A. Masdar, "Preserving Minangkabau Traditional Building in West Sumatera, Indonesia: Integration of Information Technology," in Procedia Environmental Sciences, 2013, vol. 17, pp. 749-756.

[39] Y. Setyoningrum, "MEMPERTANYAKAN KESETARAAN GENDER: BERCERMIN PADA RUANG HUNIAN TRADISIONAL INDONESIA (STUDI KASUS: RUMAH GADANG MINANGKABAU),"www.budayamelayuonline.com. [Online]. Available: https://s3.amazonaws.com/academia.edu.documents/45018795/MEMPERTANYAKA N_KESETARAAN_GENDER....pdf?AWSAccessKeyId=AKIAIWOWYYGZ2Y53U L $\overline{3}$ A\&Expires $=1553565650 \&$ Signature $=$ gKVLM2A9fAWK5UKftD4H5KSFOKQ\%3 D\&response-content-disposition=inline\%3B filename\%3DMEMPERTANY. [Accessed: 30-Mar-2018].

[40] D. Desyandri, "NILAI-NILAI EDUKATIF LAGU-LAGU MINANG UNTUK MEMBANGUN KARAKTER PESERTA DIDIK," J. Pembang. Pendidik. Fondasi dan Apl., vol. 3, no. 2, pp. 126-141, Oct. 2016.

[41] K. Saddhono, "Language and superdiversity: Indonesians knowledging at home and abroad. By Zane Goebel." Soc. Stu. vol. 12 no.1 pp. 113-118, 2018

[42] R. Mustansyir and M. Munir, "KONSEP URANG SABANA URANG DALAM PEPATAH ADAT MINANGKABAU,” J. Filsafat, vol. 19, no. 2, pp. 165-177, Sep. 2016. 